\title{
Apoptosis Induced In Vitro and In Vivo During Infection by Ebola and Marburg Viruses
}

\author{
Thomas W. Geisbert, Lisa E. Hensley, Tammy R. Gibb, Keith E. Steele, \\ Nancy K. Jaax, and Peter B. Jahrling \\ Pathology Division (TWG, LEH, TRG, KES, NKJ) and Headquarters (PBJ), US Army Medical Research Institute of \\ Infectious Diseases, Fort Detrick, Maryland
}

\begin{abstract}
SUMMARY: Induction of apoptosis has been documented during infection with a number of different viruses. In this study, we used transmission electron microscopy (TEM) and terminal deoxynucleotidyl transferase-mediated deoxyuridine triphosphate nick-end labeling to investigate the effects of Ebola and Marburg viruses on apoptosis of different cell populations during in vitro and in vivo infections. Tissues from 18 filovirus-infected nonhuman primates killed in extremis were evaluated. Apoptotic lymphocytes were seen in all tissues examined. Filoviral replication occurred in cells of the mononuclear phagocyte system and other well-documented cellular targets by TEM and immunohistochemistry, but there was no evidence of replication in lymphocytes. With the exception of intracytoplasmic viral inclusions, filovirus-infected cells were morphologically normal or necrotic, but did not exhibit ultrastructural changes characteristic of apoptosis. In lymph nodes, filoviral antigen was co-localized with apoptotic lymphocytes. Examination of cell populations in lymph nodes showed increased numbers of macrophages and concomitant depletion of $\mathrm{CD}^{+} \mathrm{T}$ cells and plasma cells in filovirus-infected animals. This depletion was particularly striking in animals infected with the Zaire subtype of Ebola virus. In addition, apoptosis was demonstrated in vitro in lymphocytes of filovirus-infected human peripheral blood mononuclear cells by TEM. These findings suggest that lymphopenia and lymphoid depletion associated with filoviral infections result from lymphocyte apoptosis induced by a number of factors that may include release of various chemical mediators from filovirus-infected or activated cells, damage to the fibroblastic reticular cell conduit system, and possibly stimulation by a viral protein. (Lab Invest 2000, 80:171-186).
\end{abstract}

$I$ nfections with filoviruses cause severe and often fatal hemorrhagic disease in humans and nonhuman primates, killing up to $90 \%$ of infected individuals. Ebola (EBO) and Marburg (MBG) viruses comprise the family Filoviridae (Murphy et al, 1995). The EBO species consists of the Zaire and Sudan subtypes first isolated during separate outbreaks in 1976, the Reston subtype initially isolated from monkeys imported from the Philippines to the United States in 1989, and the Côte d'Ivoire subtype discovered in the Tai Forest of the Ivory Coast in 1994. The recent re-emergence of EBO subtype Zaire (EBO-Z) in former Zaire and Gabon, and subtype Reston (EBO-R) in the United States, are but the last of a succession of filoviral outbreaks that have occurred sporadically since the

Received September 1, 1999.

The views, opinions, and findings contained herein are those of the authors and should not be construed as an official Department of the Army position, policy, or decision unless so designated by other documentation.

In conducting research using animals, the investigators adhered to the "Guide for the Care and Use of Laboratory Animals," prepared by the Committee on Care and Use of Laboratory Animals of the Institute of Laboratory Animal Resources, National Research Council (1996). The USAMRIID animal facilities and animal care and use program are accredited by the Association for Assessment and Accreditation of Laboratory Animal Care International.

Address reprint requests to: Dr. T. W. Geisbert, USAMRIID, Attn: MCMR-UIP-D, 1425 Porter Street, Fort Detrick, MD 21702-5011.

Fax: 301-619-4627; E-mail: tom.geisbert@amedd.army.mil initial zoonotic outbreak of MBG in 1967. Although outbreaks have been self-limiting, the lack of proven effective prophylactic or therapeutic regimens to treat filoviral infections has heightened concerns about the public health threat of these pathogens.

The factors contributing to the development of severe lesions in EBO and MBG hemorrhagic fevers are unknown. Filoviral infections of humans and nonhuman primates are characterized by a failure of the host immune response associated with the onset of marked lymphopenia, lack of inflammation in infected tissues, severe lymphoid degeneration, and lack of a humoral response in some fatal cases (Jaax et al, 1996; Peters et al, 1996). Morphological studies of EBO and MBG virus-infected primate and rodent tissues have demonstrated a predilection for liver and lymphatic tissues and showed that cells of the mononuclear phagocyte system (MPS) are primary sites of replication (Connolly et al, 1999; Geisbert and Jaax, 1998; Geisbert et al, 1992; Jaax et al, 1996; Ryabchikova et al, 1999; Zaki and Goldsmith, 1999). In addition, Feldmann et al (1996) reported that cultured human monocytes and macrophages are highly susceptible to filoviral infections resulting in cell death and massive production of infectious particles (Feldmann et al, 1996). Replication of filoviruses has been reported in other cell types including endothelial cells, epithelial cells, fibroblasts, fibroblastic reticular cells (FRC), hepatocytes, and adrenalcytes (Davis et al, 1997; Geisbert et al, 1992; Jaax et al, 1996). 
Contrary to an initial report (Baskerville et al, 1985), we showed that lymphocytes are refractory to filovirus infection in vivo and in vitro (Geisbert et al, 1992; Jaax et al, 1996; Davis et al, 1997; Geisbert and Jaax, 1998). We hypothesized that the death and depletion of lymphocytes was induced by cytokines or other mediators released from infected macrophages or possibly endotoxins. Previous studies described the destruction of lymphoid tissue and loss of lymphocytes as necrosis (Geisbert et al, 1992; Jaax et al, 1996). In a recent report, we described lymphoid cell depletion seen in B-cell follicles of EBO-Z-infected monkeys as apoptosis and/or necrosis (Davis et al, 1997). A subsequent evaluation of stored blood samples suggested that intravascular apoptosis may be associated with fatal outcome in EBO-infected patients (Baize et al, 1999). However, these studies did not definitively differentiate between apoptosis and necrotic cell death of lymphocytes or other cells. Due to the recent recognition of the apoptotic cell death pathway, much attention has been focused on distinguishing between apoptotic and necrotic cell death in viral pathogenesis. There has been much confusion and debate in the literature regarding the terminology of the processes of cell injury and cell death. Some authors recognize two types of prelethal reactions to cell injury: oncosis, and apoptosis. They use the term necrosis to describe changes secondary to cell death by any mechanism including apoptosis (Majno and Joris, 1995; Trump et al, 1997). Other authors categorize the pathways of cell death as either apoptosis or necrosis (Granville et al, 1998; Harmon et al, 1998). We have used the latter terms to simplify our findings.

Apoptosis is morphologically and biochemically distinct from necrosis (Kerr et al, 1972; Majno and Joris, 1995). These differences have been well documented in recent reviews (Granville et al, 1998; Majno and Joris, 1995). Briefly, during apoptosis cells undergo nuclear and cytoplasmic condensation and then fragment into apoptotic bodies that contain normal organelles and intact membranes. These cellular components are phagocytosed by macrophages or neighboring cells without eliciting an immune response. Necrosis, in contrast, is characterized by rapid enlargement of cells and damage to organelles and plasma membrane leading to cell lysis and an inflammatory response. A number of viruses induce apoptosis either directly (Lewis et al, 1996; Oberhaus et al, 1997) or indirectly (Carrasco et al, 1996; Finkel et al, 1995; Sur et al, 1998). In general, the molecular pathways by which viruses induce apoptosis are not well understood. Apoptosis may be initiated in response to viral proteins or cellular signals. Several cellular proteins, including bcl-2, p53, myc, and c-fos, regulate this process.

Necrosis and apoptosis can be differentiated morphologically by transmission electron microscopy (TEM) and by the pattern of DNA fragmentation (Kerr et al, 1972; Majno and Joris, 1995). TEM is currently considered to be the most reliable tool for evaluating specific modes of cell death because ultrastructural changes in cells undergoing apoptosis are highly specific (Arends and Wyllie, 1991; Harmon et al, 1998). Recently, several authors described an in situ terminal deoxynucleotidyl transferase mediated deoxyuridine triphosphate nick-end labeling (TUNEL) (DNA fragmentation) assay that permits detection of apoptosis by light microscopic examination of paraffinembedded tissue sections (Lewis et al, 1996; Oberhaus et al, 1997). The TUNEL assay is particularly useful for rapidly screening tissues for evidence of apoptosis. However, single-stranded DNA ends can be detected in necrotic cells, causing false-positive signals (Collins et al, 1997); therefore, ultrastructural surveys are usually employed in conjunction with TUNEL to confirm apoptosis.

Although there have been more than 700 fatal cases of human filoviral infection, tissues from only a handful of cases are available for study. Logistical problems including cultural mores and environmental influences have hampered the collection of useable material. Preservation of these tissues is usually poor, making any morphological interpretations difficult, including evaluation of these tissues for evidence of apoptosis. Thus, we used tissues collected from nonhuman primates experimentally infected with EBO and MBG viruses to assess the role of apoptosis in filoviral disease. The in vivo portion of this study focused on tissues that constitute the main targets for filoviral infection: liver and lymphoid tissues. We employed the in situ TUNEL assay and TEM to determine whether loss of lymphocytes in filovirus-infected tissues was caused by apoptosis or by necrosis and whether filoviruses induce apoptosis in virus-infected cells, uninfected bystander cells, or both. In addition, we inoculated peripheral blood mononuclear cells (PBMC) and microvascular endothelial cells (HMVEC) with $\mathrm{EBO}$ and MBG viruses to evaluate apoptosis in human cells in vitro. This information is needed to further our understanding of filoviral pathogenesis.

\section{Results}

Morphological Evidence of Apoptosis in Monkey Tissues

Lymphoid depletion and apoptotic lymphocytes were prominent features in the lymph nodes of monkeys infected with EBO and MBG viruses compared with the uninfected controls (Fig. 1). Lymphoid depletion affected the centers of B-cell follicles in EBO-Zinfected and MBG-infected monkeys more consistently than in lymph nodes of monkeys infected with EBO-R. There was intense TUNEL-labeling of the peripheral chromatin of some lymphocyte nuclei, imparting a crescentic staining pattern. Other apoptotic lymphocytes had somewhat smaller nuclei that were uniformly labeled. Nuclear debris was also labeled. TUNEL-positive lymphocytes or nuclear debris were most abundant in the subcapsular and medullary sinuses but were also seen within the connective tissue trabeculae, surrounding the high endothelial venules, and in the paracortex. We observed many TUNEL-positive histiocytic cells in these areas. Some of these cells were tingible body macrophages (TBM). 

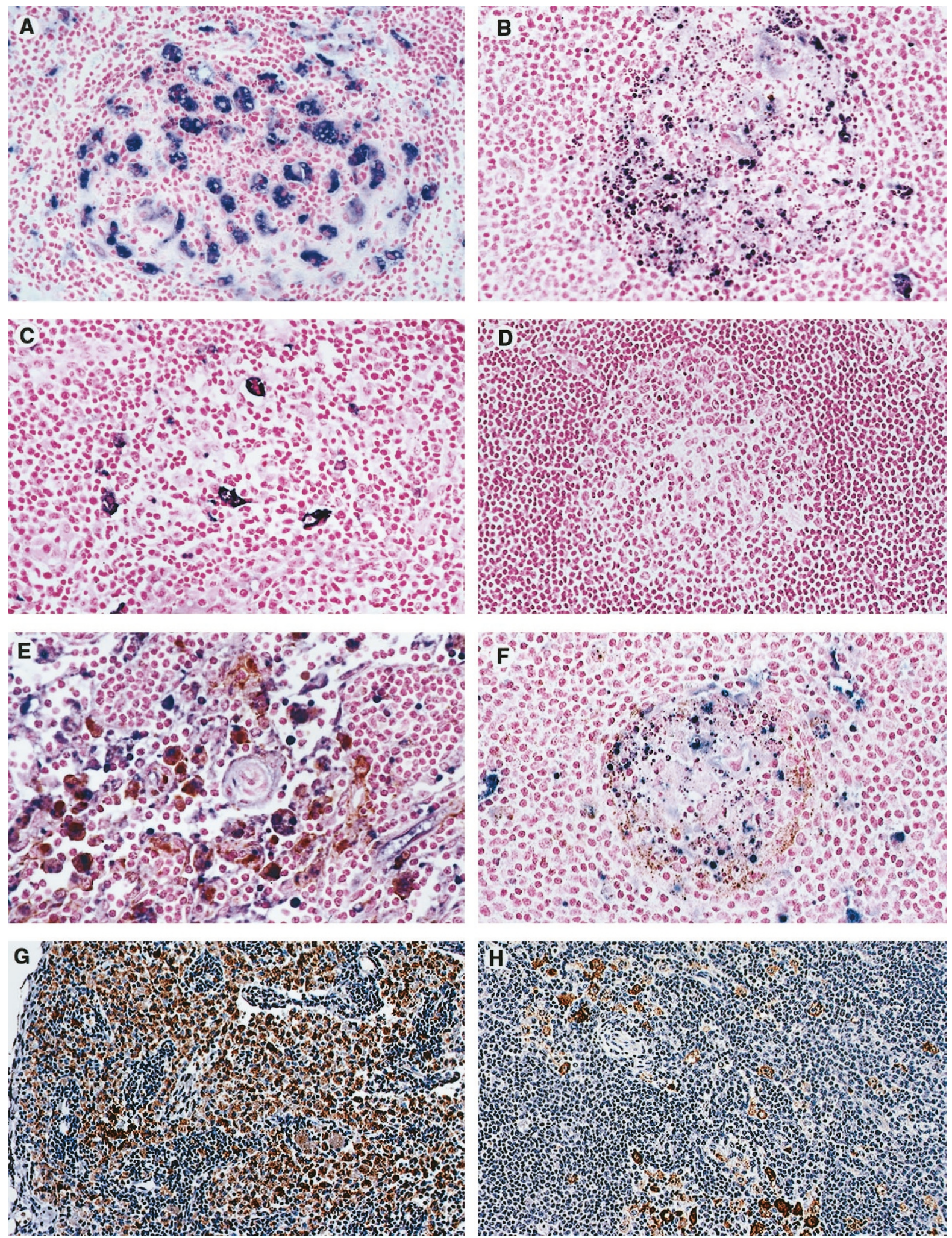

\section{Figure 1.}

Analysis of lymph node sections from filovirus-infected monkeys by deoxyuridine triphosphate nick-end labeling (TUNEL) assay for apoptosis (A-D). Single-strand breaks appear blue/black. A, Follicle center of Ebola (EBO)-Z-infected monkey congested with tingible body macrophages (TBM). B, Follicle center of Marburg (MBG)-infected monkey showing few TBM and abundant free nuclear debris. C, Follicle center of EBO-Reston (R)-infected monkey with a few TBM and little free nuclear debris. D, Follicle center of uninfected control monkey. In $E$ and $F$, labeling for apoptosis and immunohistochemistry (IHC) for filoviral antigen. E, Area from medulla of EBO-Zaire (Z)-infected monkey showing co-localization of EBO antigen (brown) and apoptotic cells. F, Follicle center of MBG-infected monkey showing co-localization of MBG antigen (brown) and apoptotic cells. In G and H, IHC for macrophage marker (shown in brown) using the Envision System (DAKO). Note increased numbers of macrophages in lymph node of EBO-Z-infected monkey $(G)$ versus MBG-infected animal $(\mathrm{H})$. Original magnifications, $\times 40$ in A-F, $\times 20$ in $G$ and $\mathrm{H}$. 
Nuclei of some TBM were unlabeled and appeared morphologically normal, whereas nuclei of other TBM were masked by intense labeling of tingible bodies in the cytoplasm. Depleted follicle centers in lymph nodes of EBO-Z-infected monkeys were frequently congested with TBM but contained little free nuclear debris (Fig. 1A). In contrast, follicle centers in lymph nodes of MBG-infected monkeys contained few TBM, although free nuclear debris was abundant (Fig. 1B). Also, fewer TBM were present in the trabeculae, medullary sinuses, and subcapsular sinuses of the lymph nodes of MBG-infected animals. The follicles in lymph nodes of EBO-R-infected monkeys showed variable TUNEL labeling. Some follicles had few TBM, and little or no nuclear debris (Fig. 1C), whereas others were consistent with follicles of EBO-Z-infected monkeys. TUNEL-positive lymphocytes and TBM were infrequently seen in lymph nodes of uninfected control monkeys. These TUNEL-positive cells were widely scattered and usually seen within the centers of follicles or in the paracortex. Many areas of the lymph nodes of uninfected animals were devoid of apoptotic lymphocytes (Fig. 1D).

TEM of lymph nodes augmented TUNEL findings and provided additional information. Lymphocyte depletion was particularly marked in nodes of all filovirus-infected monkeys when compared with uninfected controls (Table 1). This depletion was statistically significant in 13 of 18 infected monkeys. Characteristics of apoptotic lymphocytes were compaction of chromatin against the nuclear envelope and condensation of the cytoplasm. Lymphocytes in later stages of apoptosis showed fragmented nuclei and occasional convolution of the nuclear and cell outlines. Some of these cells appeared to break up into numerous membrane-bound bodies that contained various organelles and fragmented nuclei (Fig. 2). TEM showed that many macrophages had phagocytosed apoptotic bodies and apoptotic debris (Fig. 3). A number of these macrophages contained characteristic filoviral inclusions (Geisbert and Jahrling, 1995) (Fig. 4), but there was no fragmentation of macrophage nuclei in any fields surveyed. Some filovirusinfected macrophages appeared morphologically normal (with the exception of filoviral inclusions), whereas others had features consistent with necrosis. Likewise, filovirus-infected dendritic cells (Fig. 5), fibroblasts, FRC, and endothelial cells appeared structurally normal or were in various stages of necrosis, but apoptosis was not seen in any filovirus-infected cells. Lymphocytes exhibited no evidence of infection by either EBO or MBG viruses.

Stimulation of capillary and small-vessel endothelial cells, evidenced by vacuolation and cytoplasmic projections (Cheville, 1994), was observed in some fields (Fig. 6), but these cells were rarely infected. Activated endothelial cells were often seen in areas containing filovirus-infected macrophages, although some fields with high concentrations of filoviral antigen showed little or no evidence of activated or damaged endothelium (Fig. 7). Apoptotic lymphocytes and/or apoptotic bodies were sporadically seen within the endothelium of paracortical vessels (Fig. 8). Apoptotic plasma cells were occasionally observed throughout the cortex and in medullary cords of MBG and EBO$\mathrm{R}$-infected monkeys and less frequently seen in EBO-

Table 1. Lymphocyte Depletion and Apoptosis in Lymph Nodes of Nonhuman Primates

\begin{tabular}{lclccc}
\hline Species & Animal Number & Virus & Day after exposure & TLM & ALM \\
\hline A.green & 920112 & EBOZ & 6 & $16.0(5.0)$ & $1.8(1.3)$ \\
A.green & $920113^{*}$ & EBOZ & 6 & $14.1(3.8)$ & $0.5(0.7)$ \\
A.green & $920114^{*}$ & EBOZ & 6 & $13.9(3.7)$ & $0.8(0.8)$ \\
A.green & $920115^{*}$ & EBOZ & 7 & $15.0(3.9)$ & $1.5(1.3)$ \\
A.green & 990020 & Control & - & $20.3(3.7)$ & 0 \\
Cyno & 950076 & EBOZ & 6 & $16.7(4.8)$ & $0.2(0.4)$ \\
Cyno & 950079 & EBOZ & 7 & $18.3(6.6)$ & $1.5(2.5)$ \\
Cyno & 960026 & EBOZ & 7 & $15.6(5.0)$ & $0.3(0.7)$ \\
Cyno & $970016^{*}$ & EBOZ & 6 & $10.9(2.3)$ & $0.5(0.7)$ \\
Cyno & $970017^{*}$ & EBOZ & 6 & $13.1(3.6)$ & $0.2(0.4)$ \\
Cyno & $980024^{*}$ & MBG & 9 & $13.6(3.5)$ & $0.4(0.7)$ \\
Cyno & $980025^{*}$ & MBG & 9 & $12.3(3.9)$ & $0.3(0.5)$ \\
Cyno & $980026^{*}$ & MBG & 10 & $11.5(2.9)$ & $1.8(2.0)$ \\
Cyno & $980067^{*}$ & MBG & 10 & $12.8(5.5)$ & $0.8(0.8)$ \\
Cyno & $900137^{*}$ & EBOR & 11 & $13.7(4.6)$ & $2.3(1.6)$ \\
Cyno & $960167^{*}$ & EBOR & 15 & $12.1(3.2)$ & $1.0(1.5)$ \\
Cyno & 990022 & Control & - & $20.4(3.5)$ & 0 \\
Rhesus & 950051 & EBOZ & 8 & $18.4(3.2)$ & $0.7(0.5)$ \\
Rhesus & $950064^{*}$ & EBOZ & 7 & $16.6(3.4)$ & $0.1(0.3)$ \\
Rhesus & $950065^{*}$ & EBOZ & 8 & $14.2(2.9)$ & $0.9(1.0)$ \\
Rhesus & 990021 & Control & - & $23.5(5.7)$ & 0 \\
\hline
\end{tabular}

Results are mean number (SD) of total lymphocytes (TLM) and mean number (SD) of apoptotic lymphocytes (ALM) counted in 12 electron micrographs (at $\times 2000)$ from each animal.

* Values are significantly different from those of control species. $p<0.01$ 


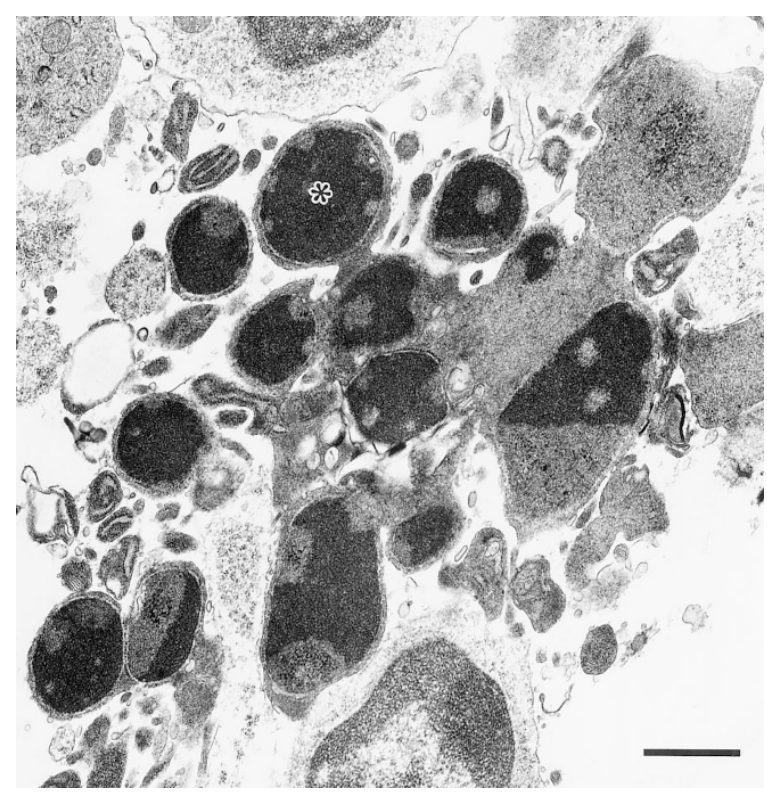

\section{Figure 2.}

Transmission electron microscopy (TEM) of inguinal lymph node from EBO-Z-infected cynomolgus monkey. Lymphocyte in late stage of apoptosis showing break-up of cell into numerous bodies most of which contain nuclear fragments ( ${ }^{*}$. Bar $=1.0 \mu \mathrm{m}$.

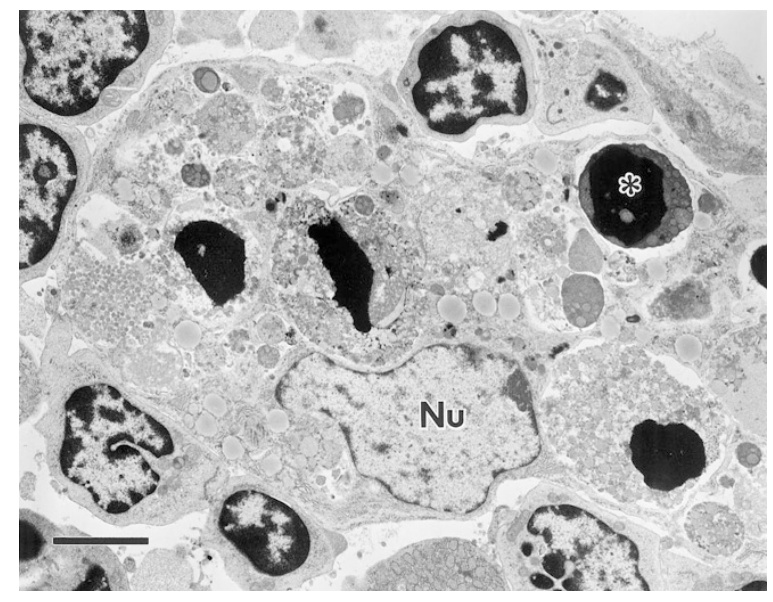

Figure 3.

TEM of mesenteric lymph node from EBO-R-infected cynomolgus monkey. Apoptotic bodies ( $)$ in cytoplasm of cortical macrophage. Note that nucleus of macrophage $(\mathrm{Nu})$ shows no signs of fragmentation. Bar $=3.5 \mu \mathrm{m}$.

Z-infected animals. Nonviral tubuloreticular inclusions (Grimley et al, 1983; Geisbert et al, 1992) were sometimes seen in endothelial cells and leukocytes of all infected animals and were more frequently seen than filoviral inclusions in endothelial cells.

Differences with regard to types or numbers of apoptotic cells among the three species of nonhuman primates were not apparent. Lymph nodes of African green monkeys appeared to have higher numbers of EBO-Z-infected endothelial cells when compared with the Asian macaques, but individual variation was obvious among all species including the African green monkeys. By TEM, there was a clear association between lymphocyte apoptosis and adjacent filoviral

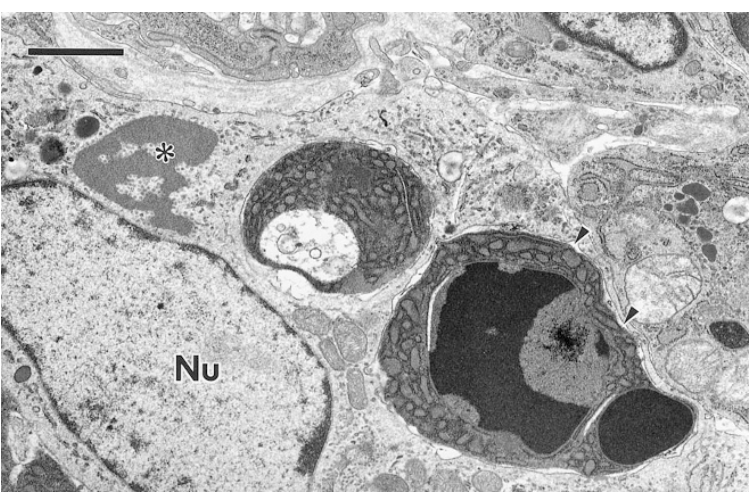

Figure 4.

TEM of inguinal lymph node from MBG-infected cynomolgus monkey. Apoptotic plasma cell (arrowheads) engulfed by cortical macrophage. Note the MBG inclusion $\left({ }^{*}\right)$ in cytoplasm and normal appearance of macrophage nucleus $(N u)$. Bar $=1.5 \mu \mathrm{m}$.

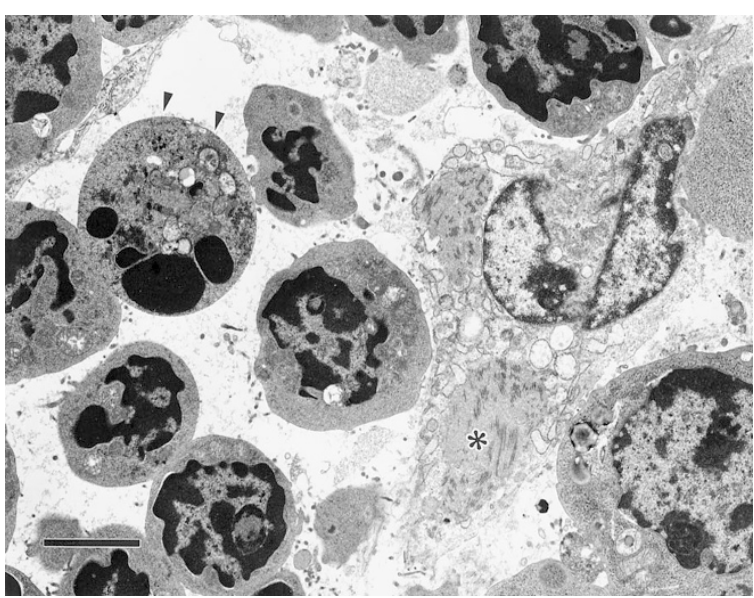

\section{Figure 5.}

TEM of axillary lymph node from EBO-Z-infected rhesus monkey. EBO inclusion material ${ }^{*}$ ) in cytoplasm of degenerative dendritic cell in T cell area. Note the apoptotic lymphocyte (arrowheads) in field. Bar $=3.5 \mu \mathrm{m}$.

antigen. Apoptotic lymphocytes were more frequently seen in fields that contained EBO or MBG virions or virus-infected cells than in fields with no antigen. In many fields, apoptotic lymphocytes were closely apposed to EBO antigen (Fig. 9) or MBG antigen (Fig. 10). As shown in Figure 11, by simple linear regression, apoptosis and filoviral infection were significantly related ( $\left.p=0.005, r^{2}=0.55\right)$ in nonhuman primates.

Examination of liver sections from the filovirusinfected monkeys showed little evidence of apoptosis. An occasional TUNEL-positive lymphocyte was seen in circulation, and small foci of TUNEL-positive hepatocytes were seen in a few EBO-Z-infected monkeys. TEM showed frequent filoviral infection of hepatocytes (Fig. 12) and Kupffer cells and occasional infection of sinusoidal lining cells, but these cells appeared normal or necrotic rather than apoptotic. Although high background labeling of spleen from filovirus-infected animals precluded evaluation by the TUNEL assay, ultrastructural examination showed extensive necrosis of MPS cells, frequent apoptosis of lymphocytes, and 


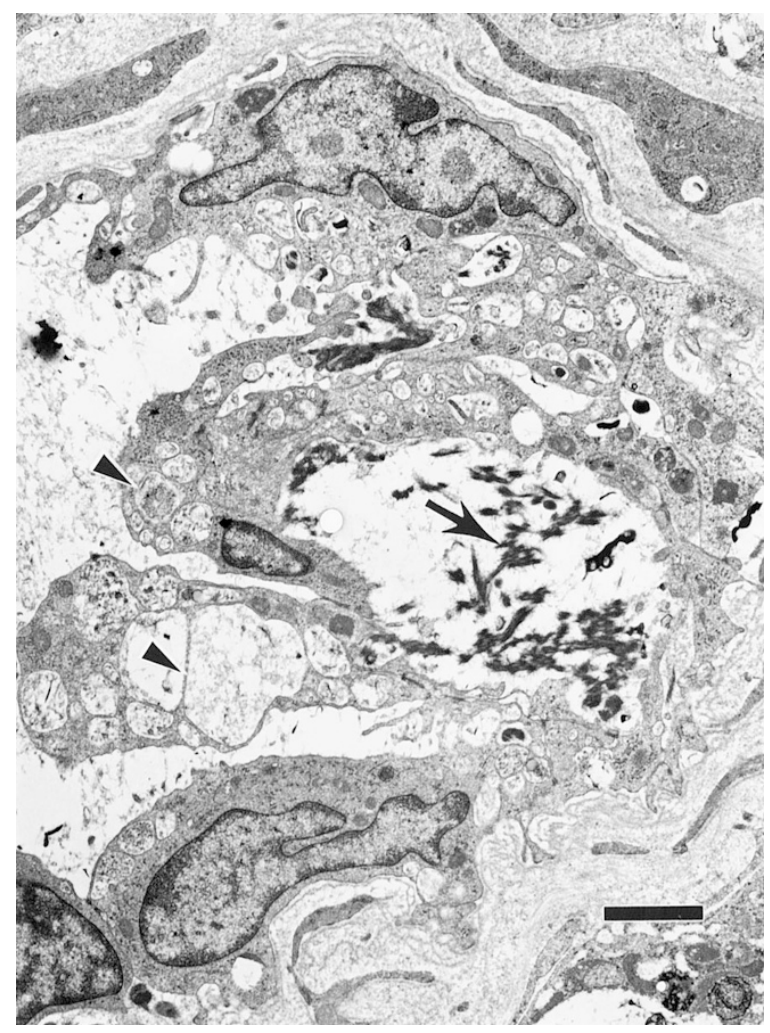

Figure 6.

TEM of inguinal lymph node from EBO-Z-infected cynomolgus monkey. The endothelial cells show evidence of stimulation (arrowheads). Note the fibrin deposits (arrow) where an endothelial cell has detached from basement membrane. Bar $=2.0 \mu \mathrm{m}$.

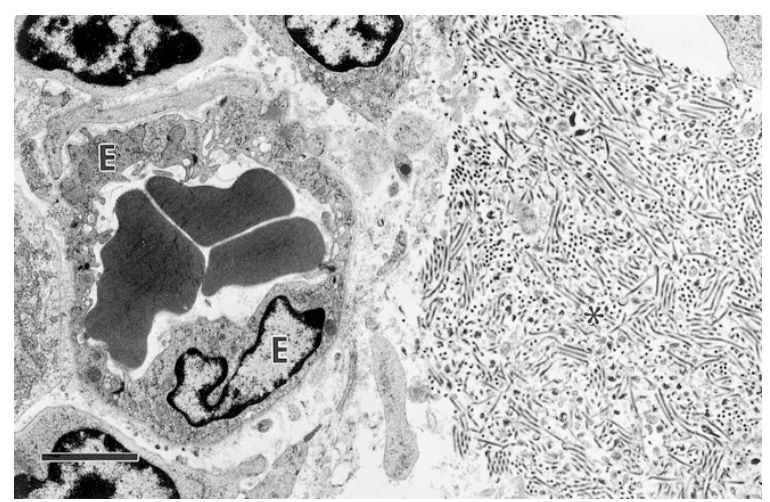

\section{Figure 7.}

TEM of mesenteric lymph node from EBO-R-infected cynomolgus monkey. Endothelial cells $(E)$ of small vessel in cortex shows no signs of infection or disruption. Note the large cluster of virions ( ${ }^{*}$ ) adjacent to abluminal side of endothelium. Bar $=2.5 \mu \mathrm{m}$.

widespread deposition of fibrin. Filoviral inclusion material was seen in some of the degenerate MPS cells, particularly in the EBO-infected animals. Spleens of EBO-infected monkeys had larger and more frequent deposits of fibrin, larger numbers of free virions, and more necrotic cellular debris than spleens of MBGinfected animals. TEM of uninfected tissues rarely showed lymphocyte apoptosis.

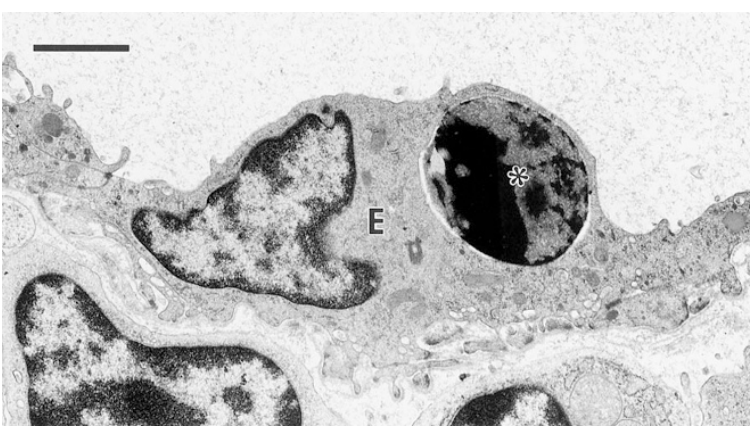

Figure 8.

TEM of mesenteric lymph node of EBO-Z-infected rhesus monkey. Apoptotic body $\left(^{*}\right)$ has appearance of a small lymphocyte surrounded by endothelial cell (E). Bar $=1.7 \mu \mathrm{m}$.

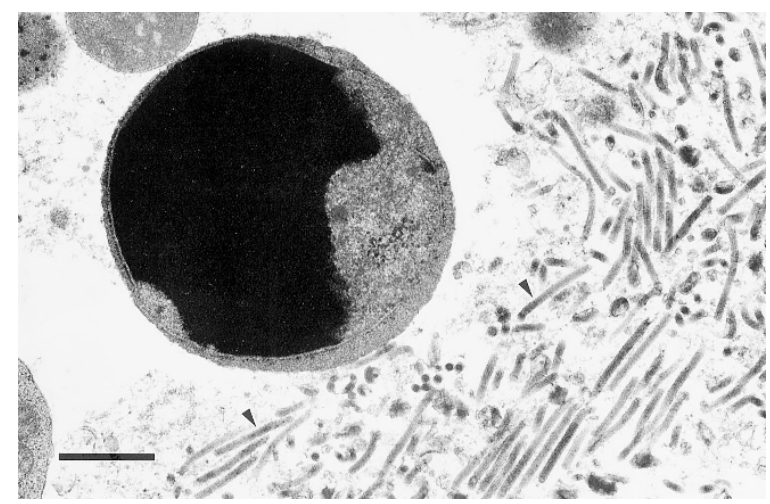

Figure 9.

TEM of mesenteric lymph node of EBO-Z-infected African green monkey. EBO virions (arrowheads) closely apposed to apoptotic lymphocyte in subcapsular sinus. $\mathrm{Bar}=855 \mathrm{~nm}$.

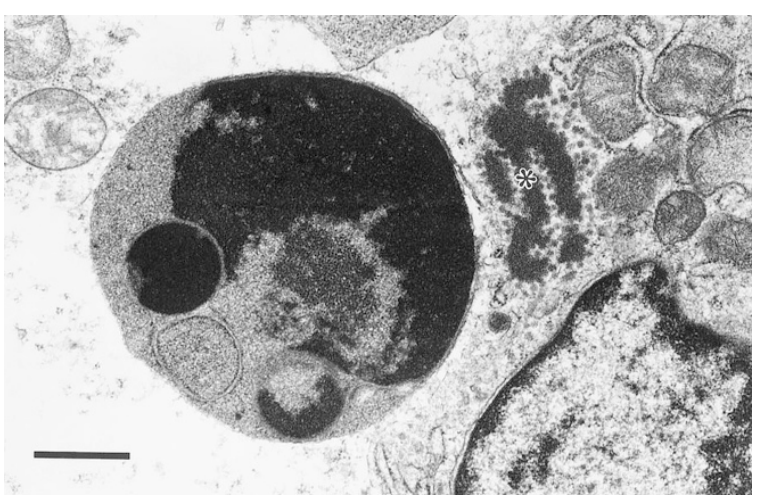

Figure 10.

TEM of inguinal lymph node of MBG-infected cynomolgus monkey. MBG viral inclusion (*) in cytoplasm of macrophage apposed to apoptotic lymphocyte in subcapsular sinus. Bar $=935 \mathrm{~nm}$.

\section{Double-Labeling Experiments}

To evaluate the relative contributions of direct or indirect killing in filoviral infections, sections of lymph nodes were analyzed microscopically for filoviral antigen by immunohistochemistry $(\mathrm{IHC})$ and concurrently for apoptosis by TUNEL assay. In all infected regions of lymph nodes, lymphocytes were positive by 


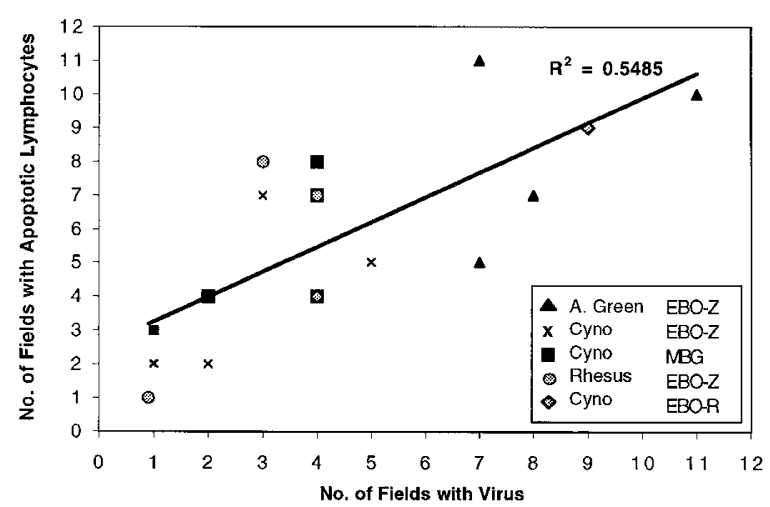

Figure 11.

Correlation between apoptosis and filoviral infection in lymph nodes by TEM. For each monkey, the number of representative non-overlapping fields (of 12 fields employed) containing apoptotic lymphocytes or filoviral antigen was counted at a magnification of $\times 2000$. Each point represents the scoring result of a single monkey. The solid line represents the best fit by linear regression.

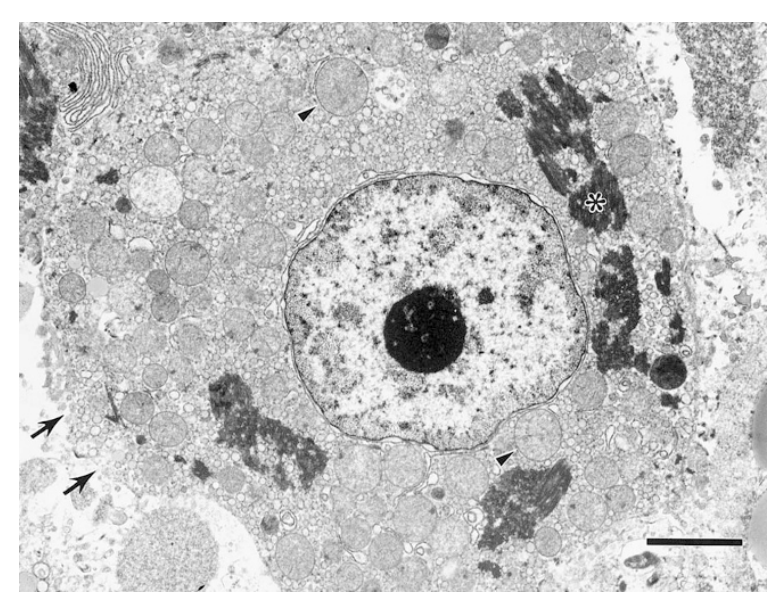

Figure 12.

TEM of liver of EBO-Z-infected cynomolgus monkey. Hepatocyte contains EBO inclusion material $\left({ }^{*}\right)$ and shows ultrastructural features consistent with necrosis including swollen mitochondria (arrowheads) and focal membrane disruption (arrows). Bar $=2.3 \mu \mathrm{m}$.

TUNEL, but negative by IHC. Only macrophages contained both filoviral antigens and fragmented DNA. As described above, TEM confirmed that these macrophages had phagocytosed apoptotic bodies, but macrophage nuclei were morphologically normal (Figs. 3 and 4). In both EBO and MBG-infected tissues TUNEL-positive lymphoid cells and nuclear debris were most frequently seen in areas that also were IHC-positive for filoviral antigen (Fig. 1, E and F).

To show the phenotypic distribution of the apoptotic lymphocytes, sections of lymph nodes were concurrently stained for apoptosis by TUNEL assay and expression of CD3 (T-cell), CD20 (B-cell), a plasma cell marker, and human leukocyte antigen L1 protein (a macrophage marker) by IHC. Double labeling showed $\mathrm{CD}^{+}{ }^{+}$lymphocytes, CD20 ${ }^{+}$lymphocytes, and plasma cells in lymph nodes of EBO- and MBG-infected monkeys with TUNEL-positive nuclei and demonstrated $\mathrm{CD}^{+}, \mathrm{CD}^{+} \mathrm{O}^{+}$, and plasma cell-positive tingible bodies in macrophages (Figs. 13 and 14, A to F).
Apoptotic $\mathrm{CD}^{2} \mathrm{O}^{+}$lymphocytes were less frequently seen than apoptotic $\mathrm{CD}^{+}$lymphocytes, particularly in lymph nodes of MBG-infected monkeys. Double labeling for the macrophage marker and apoptosis confirmed that TBM were not undergoing apoptosis, with positive labeling limited to the cytoplasm. Close examination of TBM showed numerous apoptotic bodies within a single macrophage (Fig. 14, C and D).

Examination of the distribution of cell markers showed depletion of $\mathrm{CD}^{2} \mathrm{O}^{+}$cells from germinal centers concomitant with increased numbers of $\mathrm{CD}^{+}$ cells. B-cell depletion and loss of germinal centers was more striking in EBO-infected monkeys with depletion being most severe in EBO-Z-infected animals. We observed $\mathrm{CD}^{+}$or $\mathrm{CD}_{2}{ }^{+}$tingible bodies in macrophages in germinal centers and throughout the nodes of all filovirus-infected monkeys supporting the observation that $\mathrm{CD}^{+}$and $\mathrm{CD}^{+} \mathrm{O}^{+}$cells were undergoing apoptosis (Figs. 13 and 14, A to D). Fewer plasma cells were observed in lymph nodes of filovirus-infected monkeys than in uninfected control animals, and there were fewer plasma cells in EBOZ-infected animals than in other filovirus-infected monkeys. There were increased numbers of macrophages in lymph nodes of all filovirus-infected monkeys. The presence of macrophages in germinal centers was especially marked in EBO-Z-infected animals and was somewhat less evident in EBO-R- and MBGinfected monkeys, respectively. The observed loss of plasma cells and increased presence of macrophages in EBO-Z-infected animals was corroborated by a second IHC procedure employing the Envision System (DAKO, Carpinteria, California) (Figs. 1, G to $\mathrm{H}$, and 14, E to H). Although double-labeling for CD4 and CD8 proved incompatible with pretreatment steps for detecting single-strand breaks, staining for these markers by the Envision System (DAKO) showed increased numbers of $\mathrm{CD} 4^{+} \mathrm{T}$ cells in germinal centers of all filovirus-infected monkeys. There was an apparent decrease in the overall number of $\mathrm{CD} 4^{+}$cells, and a marked depletion of $\mathrm{CD}^{+} \mathrm{T}$ cells in lymph nodes of EBO-Z-infected animals (data not shown). This depletion of $\mathrm{CD}^{+} \mathrm{T}$ cells was less striking in EBO-R- and MBG-infected monkeys. We observed $\mathrm{CD}^{+}$and $\mathrm{CD}^{+}$tingible bodies in macrophages of EBO-Zinfected monkeys, suggesting that both $\mathrm{CD}^{+}$cells and $\mathrm{CD}^{+}$cells were undergoing apoptosis.

\section{Ultrastructural Evaluation of Filovirus-Infected PBMC and HMVEC In Vitro}

Ultrastructural examination of PBMC showed higher numbers of apoptotic lymphocytes in EBO-Z-infected cultures at Days 4 and 6 postinfection (PI), and MBGinfected cultures at Day $6 \mathrm{PI}$, versus uninfected PBMC (Table 2). Differences in numbers of apoptotic lymphocytes were not apparent between EBO-R-infected cultures and uninfected PBMC. There were filoviral inclusions in monocytes and macrophages of all filovirus-infected cultures, but these were never seen in lymphocytes. More than half of the filovirus-infected monocytes or macrophages contained viral inclusion 

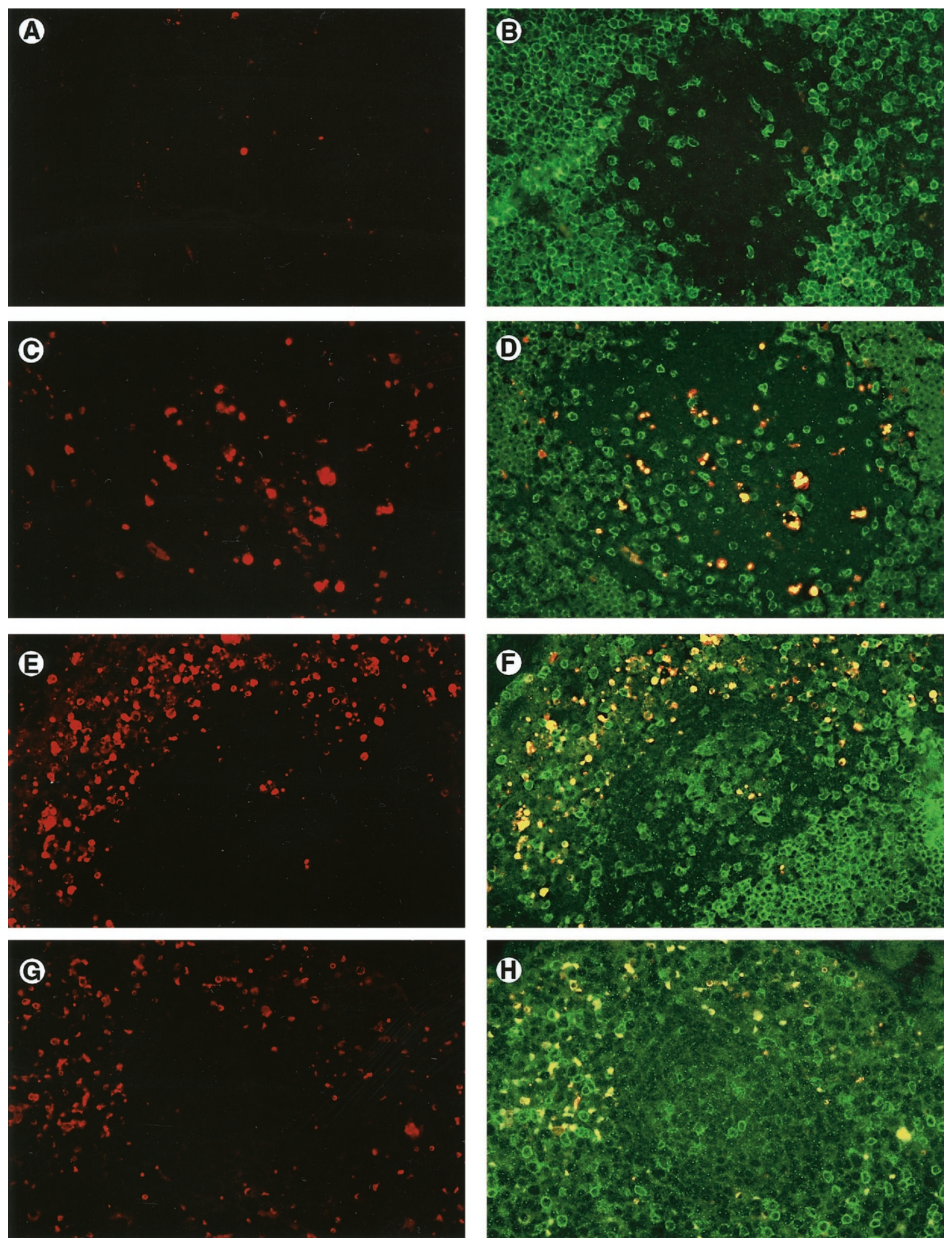

Figure 13.

Examination of apoptosis using a wide-band green filter (A, C, E, and G) and double labeling for apoptosis and CD3 using a dual pass FITC/TRITC filter (B, D, F, and $\mathrm{H})$ in mesenteric lymph nodes of filovirus-infected monkeys. Single-strand breaks are shown in red, CD3 appears green, and areas positive for both apoptosis and CD3 are stained gold. In $A$ and $B$, section from uninfected control animal showed infrequent apoptotic cells (A) and no visible apoptotic $\mathrm{CD3}^{+}$cells $(B)$. The number of apoptotic cells was increased in EBO-Z- (C), EBO-R- (E), and MBG-infected (G) monkeys. Double labeling showed the presence of apoptotic $\mathrm{CD}^{+}{ }^{+}$cells in follicles and perifollicular areas of EBO-Z- (D), EBO-R- $(\mathrm{F})$, and MBG-infected $(\mathrm{H})$ monkeys. Also, increased numbers of $\mathrm{CD}^{+}$cells are evident within the follicle centers of EBO-Z- (D) and EBO-R-infected (F) animals versus uninfected control monkey (B). Original magnifications, $\times 40$ in A-H. 

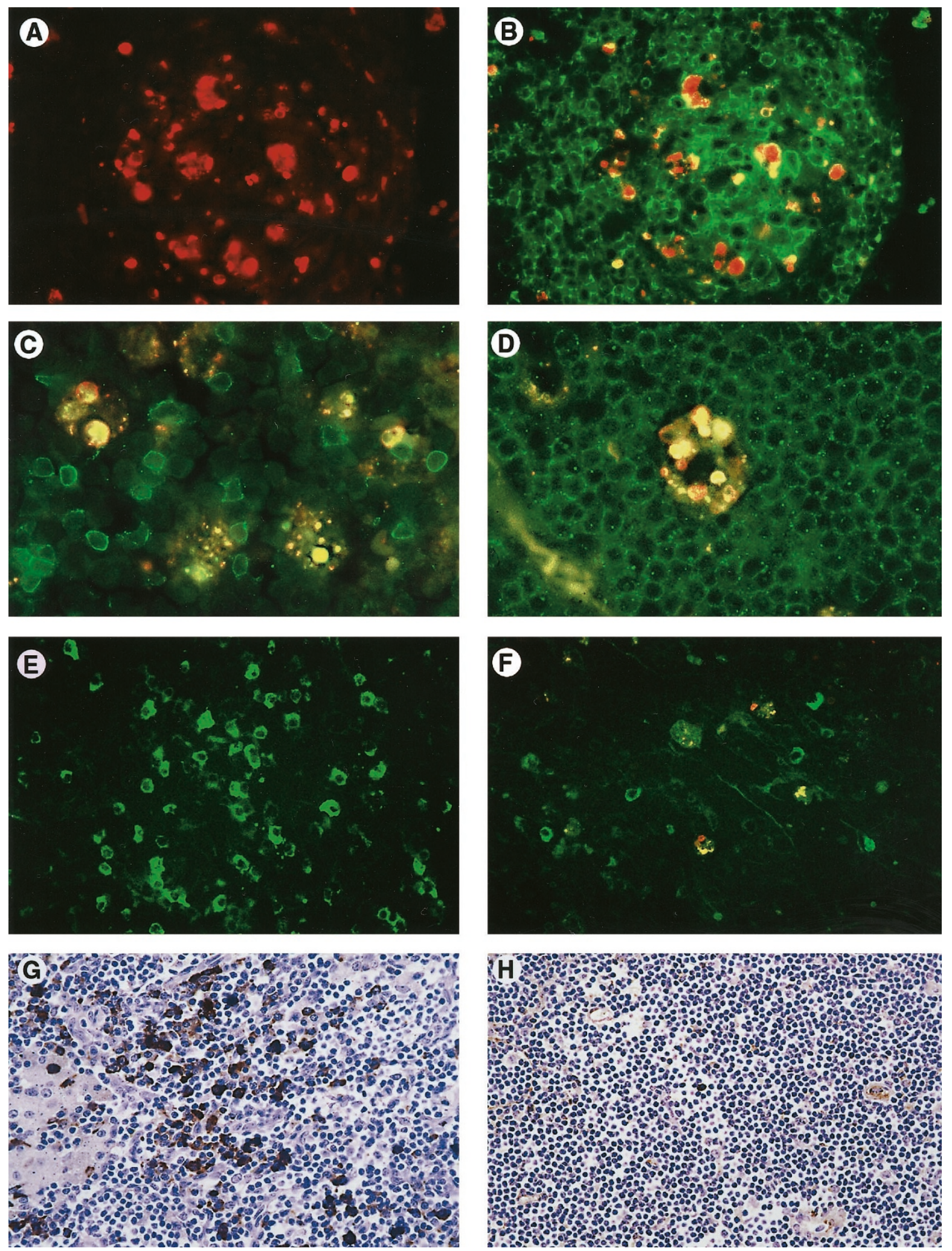

\section{Figure 14}

Analysis of mesenteric lymph node sections from filovirus-infected monkeys. Examination of apoptosis using a wide-band green filter (A) and double labeling for apoptosis and CD20 (B and D), CD3 (C), or plasma cell marker (E and F) using a dual pass FITC/TRITC filter. In A-F, single-strand breaks are shown in red, cell markers appear green, and areas positive for both apoptosis and the cell marker appear gold. Staining for apoptosis revealed increased numbers of apoptotic cells and/or material in follicles of EBO-Z-infected animals (A). Dual staining showed apoptotic CD20+ cells in EBO-Z-infected monkeys (B). In C and D, examination of TBM from sections double-labeled for CD3 and apoptosis (C) (EBO-R) or CD20 and apoptosis (D) (MBG) showed apoptotic material positive for either CD3 or CD20 in cytoplasm of TBM. Nuclei of TBM in these fields are not labeled for apoptosis. Double labeling showed a decreased number of plasma cells in EBO-R-infected monkey (F) versus uninfected control (E). Also, note plasma cell-positive tingible bodies in macrophages (F). In G-H, IHC for cell markers using the Envision System (DAKO). Cell markers are shown in brown. Plasma cells were less frequently seen in lymph node sections of EBO-Z-infected animal $(\mathrm{H})$ versus uninfected controls (G). Original magnifications: $\times 60$ in $\mathrm{A}$ and $\mathrm{B}, \times 100$ in $\mathrm{C}$ and $\mathrm{D}, \times 40$ in $\mathrm{E}-\mathrm{H}$ 
Table 2. Lymphocyte Apoptosis in PBMC In Vitro

\begin{tabular}{cccc}
\hline Virus & Days PI & TL & $\mathrm{AL}$ \\
\hline Control & 4 & 329 & 11 \\
Control & 6 & 297 & 11 \\
EBO-Z & 4 & 306 & 24 \\
EBO-Z & 6 & 231 & 45 \\
EBO-R & 4 & 266 & 9 \\
EBO-R & 6 & 238 & 8 \\
MBG & 4 & 251 & 14 \\
MBG & 6 & 234 & 38 \\
\hline
\end{tabular}

Results are the number of total lymphocytes (TL) and the number of apoptotic lymphocytes $(\mathrm{AL})$ counted in 30 TEM fields $($ at $\times 2000)$ from each PBMC culture.

$\mathrm{PI}$, postinfection.

material at Day $6 \mathrm{PI}$. Apoptosis of monocytes or macrophages was not observed in any PBMC culture. In addition, we did not see any evidence of apoptosis in any HMVEC culture. Numbers of filovirus-infected HMVEC increased from Day $4 \mathrm{PI}$ to Day $6 \mathrm{PI}$, with more than half of the EBO-Z- and MBG-infected HMVEC containing filoviral inclusions at Day $6 \mathrm{PI}$. Filoviral inclusions were infrequently seen in HMVEC infected with EBO-R at either time point. With the exception of the intracytoplasmic viral inclusions, infected HMVEC appeared morphologically normal or were necrotic.

\section{Discussion}

EBO and MBG hemorrhagic fevers are characterized by lymphopenia, with destruction of lymphoid tissue among the main features of the disease (Peters et al, 1996). Destruction and/or depletion of lymphocytes in lymphoid tissue has historically been attributed to necrosis (Geisbert et al, 1992; Jaax et al, 1996). In this study, lymphocyte death was shown by TEM and TUNEL assay to be induced by apoptosis. Cells undergoing necrosis as a result of the cytopathogenic effect of filoviral replication included cells of the MPS, hepatocytes, fibroblasts, FRC, and endothelial cells, but apoptosis affected only lymphocytes. Apoptosis of lymphocytes is not unique to filoviruses; it has also been reported independent of viral replication in HIV and SIV infections (Finkel et al, 1995), African swine fever virus infections (Carrasco et al, 1996; Oura et al, 1998), and porcine reproductive and respiratory syndrome virus infections (Sur et al, 1998).

In the lymphoid tissues evaluated in this study, we observed an association, in terms of both location and intensity, between lymphocyte apoptosis and filoviral replication in MPS cells or in other cells. Also, we demonstrated apoptosis of lymphocytes in cultures of EBO-Z- and MBG-infected human PBMC. Although filoviral replication was not seen in lymphocytes, the monocyte fraction of PBMC supported and maintained viral growth. These observations suggest that lymphocyte apoptosis may be induced by the release of chemical mediators from virus-infected cells, stimulation with a viral protein, and/or interaction with other cells. Macrophages produce several mediators capable of inducing apoptosis, including TNF- $\alpha$, nitric oxide, reactive oxygen species, and IL-1 $\beta$ (Kolesnick and Golde, 1994; Martin and Edwards, 1993; Messmer et al, 1994; Tracey and Cerami, 1992). When stimulated as a result of viral replication or virus-cell interactions, release of these chemical mediators from MPS cells can induce apoptosis in nearby lymphocytes. Also, activated lymphocytes can express Fas and Fas ligand and become sensitive to Fas-mediated apoptosis (Eischen and Leibson, 1997). Kayagaki et al (1999) reported that type I IFN enhance TNF-related apoptosis-inducing ligand (TRAIL) expression on human $T$ cells, making them susceptible to TRAILinduced apoptosis. Our data suggest that a similar mechanism may be involved in filoviral infections. Tubuloreticular inclusions were demonstrated in endothelial cells and leukocytes of filovirus-infected monkey tissues. These inclusions have been associated with production of IFN- $\alpha$ (Geisbert et al, 1992; Grimley et al, 1983). Furthermore, we detected increased levels of IFN- $\alpha$ in terminal sera of EBOinfected monkeys (PB Jahrling, unpublished observation). Other recent studies suggest that cytokines may play an important role in filoviral disease. Elevated cytokine levels were shown in acute sera of patients infected with EBO-Z in former Zaire (Villinger et al, 1999) as well as from filovirus-infected monkeys (Ignat'ev et al, 1996).

Apoptosis of lymphocytes in filovirus-infected tissues could be mediated by stimulation with a structural or virus-induced protein. Studies of HIV-infected monocytes suggested that interaction of CD4 with expressed gp120 in conjunction with other cell surface proteins may predispose cells to undergo apoptosis in the absence of viral infection (Coito and Bomsel, 1999). Although lymphocytes were nonpermissive to filoviral infection, interactions with viral glycoproteins and cell surface molecules have not been evaluated. The release of viral glycoproteins in non-virion form resulting from cell lysis, proteolytic cleavage, or shedding of non-membrane associated subunits is reported for other viruses (Little and Huang, 1978; Veronese et al, 1985). Volchkov (1999) recently reported that during EBO infection a nonstructural soluble glycoprotein plus several forms of glycoprotein are secreted from the surface of productively infected cells. Thus, these EBO viral proteins may act on neighboring cells that have not been infected. Alternatively, this function may be accomplished by direct external attachment of whole filoviral particles to the cell without penetration or ensuing viral infection.

Consistent with a previous report (Davis et al, 1997), FRC and dendritic cells were targets of infection by filoviruses in our study. The importance of the FRC conduit network in regulating lymphocyte migration and promoting lymphocyte viability was addressed in a number of recent reviews (Gretz et al, 1996; Rosenberg et al, 1998). This network consists of reticular fibers, related extracellular matrix components, and associated FRC. The network provides a threedimensional scaffold for attachment of antigen- 
presenting cells and pathways for migration of $T$ cells to these cells. Migrating lymphocytes encounter dendritic cells and macrophages localized along the fibers. Dendritic cells provide nonspecific signals that promote lymphocyte proliferation and viability (Tew et al, 1997). Grosjean et al (1997) reported that infection of 10 human dendritic cells with measles virus blocked the stimulatory function of $10^{4}$ uninfected dendritic cells. Follicular dendritic cells were also shown to inhibit programmed cell death. Apoptosis of B cells in germinal centers was prevented by a rapid inactivation of pre-existing endonuclease (Lindhout et al, 1995). Carroll (1998) reported that blockade of contact between B cells and complement C3d-decorated follicular dendritic cells interferes with the survival signal delivered by the dendritic cells via CD21. Furthermore, dendritic cells express B7 molecules (Lu et al, 1997). Direct ligation of CD28, expressed on T cells, by B7 concomitant with anti-Fas challenge protects $T$ cells from apoptosis (Walker et al, 1998). In this study we found an association between filoviral infection of FRC and dendritic cells and apoptosis of nearby lymphocytes. It is conceivable that loss and/or dysfunction of FRC and dendritic cells caused by viral infection may result in lymphocyte apoptosis.

Additional factors may contribute to the depletion of $\mathrm{CD}^{+}$cells and plasma cells observed in lymph nodes of EBO-Z-infected monkeys. Migration of $\mathrm{CD}^{+} \mathrm{T}$ cells and plasma cell precursors into other tissues may account for some of this depletion. Recent studies suggested that $\mathrm{CD}^{+}{ }^{+} \mathrm{T}$ cell interactions with $\mathrm{B}$ cells via the Fas ligand may predispose $B$ cells to undergo apoptosis through the Fas pathway (Schattner and Friedman, 1996). The increased number of $\mathrm{CD}^{+}{ }^{+} \mathrm{T}$ cells and apoptotic cells seen in germinal centers of filovirus-infected monkeys suggests that Fas ligand interaction may not only be important for the observed plasma cell apoptosis, but may also be involved in germinal center disruption. Finally, a report demonstrating selective depletion of $\mathrm{CD}^{+}{ }^{+} \mathrm{T}$ cells by cross-linking of the cell surface ganglioside GM1 (Nahar et al, 1996) raises the possibility of selective apoptosis of individual cell phenotypes through this or similar mechanisms.

It is intriguing that, while apoptotic lymphocytes were commonly seen in filovirus-infected tissues and cultures of human PBMC, apoptosis was not seen in filovirus-infected cells. These observations raise questions regarding the causes and implications of a productive infection that does not induce apoptosis. Viral gene products that inhibit cellular apoptosis have been identified for several other viruses. Specifically, Epstein-Barr virus encodes LMP1, a protein that induces bcl-2, which in turn inhibits apoptosis (Henderson et al, 1991); adenovirus encodes E1B, a protein that inhibits E1A-induced apoptosis (Debbas and White, 1993); and African swine fever virus encodes p21, a bcl-2 homologous protein (Afonso et al, 1996). It is likely that filoviruses encode proteins or mediators that inhibit apoptosis of their host cells. Obviously, this strategy would provide a selective advantage to the virus, as any such genes may promote survival of infected cells resulting in a more productive infection. Moreover, Griffith et al (1999) showed that stimulation of monocytes by IFNs caused a loss of TRAIL receptor 2 expression and a concomitant resistance to TRAILmediated apoptosis. As addressed above, increased terminal levels of IFN- $\alpha$ are associated with filoviral infections of nonhuman primates. IFN- $\gamma$ release in plasma was recently found to be associated with fatal human EBO infections (Baize et al, 1999).

Although we observed significant levels of apoptosis in lymphocytes, our failure to detect apoptotic endothelial cells raises questions concerning the role of the endothelial cell in filoviral disease. A number of studies associate the hemorrhagic pathology and endothelial cell involvement reported in EBO and MBG infections with direct viral infection of endothelial cells. Yang et al (1998) suggested that EBO infection of endothelial cells may cause the hemorrhagic diapedesis in guinea pigs. Studies showing infection of endothelial cells by MBG and EBO viruses in vitro (Geisbert and Jaax, 1998; Schnittler et al, 1993) and filovirusinfected endothelial cells in postmortem tissues from humans and nonhuman primates (Baskerville et al, 1985; Davis et al, 1997; Geisbert et al, 1992; Jaax et al, 1996; Zaki and Goldsmith, 1999) have been used to support these views. More recent studies employing serially collected rodent and monkey tissues show that endothelial cell infection is, in fact, primarily associated with later stages of infection (Connolly et al, 1999; Ryabchikova et al, 1999). As shown in this and other studies (Geisbert et al, 1992; Jaax et al, 1996; Davis et al, 1997), the magnitude of endothelial cell infection differs among primate species and individual animals. Many TEM fields in filovirus-infected tissues show endothelial damage with no evidence of direct endothelial cell infection. In tissues of the one fatal human case of MBG hemorrhagic fever we examined, we did not see any endothelial cell infection (Geisbert and Jaax, 1998). Clearly, endothelial cell disruption, as shown in Figure 6, is not the direct result of filoviral infection. Rather, an indirect mechanism such as an aberrant cytokine profile may be responsible for the hemorrhagic pathology. Vascular changes observed in filoviral hemorrhagic fever have been related to the virus-induced release of cytokines by MPS cells (Feldmann et al, 1996). Our data support the premise that disruption of endothelium is due to a number of factors including release of various chemical mediators from filovirus-infected cells and, to a lesser degree, cytolysis caused by viral infection. Regardless of the cause of disruption, endothelial cell activation may contribute to the pathogenic processes of filoviral disease. Fehsel et al (1996) showed that activated endothelial cells produced high concentrations of nitric oxide, which, in turn, triggered apoptosis of thymocytes. It is likely that activation of endothelial cells contributed to the observed apoptosis of lymphocytes in tissues of these monkeys.

Although TUNEL and other assays that detect DNA strand breaks are convenient for rapidly screening samples, this study clearly showed the limitations of TUNEL. Precise localization of TUNEL-positive signals 
can be difficult. Macrophages that had phagocytosed apoptotic bodies and debris were seen as TUNELpositive cells, but TEM definitively showed that macrophage nuclei were not fragmented. Also, detection of DNA strand breaks in necrotic cells confused interpretation. There were TUNEL-positive hepatocytes in a few animals, and spleens of most monkeys showed high background labeling that confounded interpretation. TEM showed that hepatocytes were actually undergoing necrosis related to the viral infection rather than apoptosis. While apoptotic lymphocytes and products of apoptosis were abundant in monkey spleens, the numbers did not correspond with the overwhelming TUNEL signal. It is likely that massive necrosis of MPS cells, and possibly large fibrin deposits, contributed to the overwhelming TUNEL signal. These findings show that results obtained from assays based on detection of DNA strand breaks should be interpreted with caution, and significant findings should always be corroborated by ultrastructural analysis.

This paper provides the first morphological evidence of apoptosis in tissues of monkeys experimentally infected with filoviruses. Apoptotic lymphocytes were more frequently seen in diffuse lymphoid tissue than in follicles of filovirus-infected animals. The abundance of TUNEL-positive macrophages in lymphocyte-depleted B-cell follicles and germinal centers of EBO-infected animals suggests that substantial lymphocyte apoptosis preceded macrophage infiltration. In contrast, in MBGinfected monkeys, minimal infiltration of macrophages in these areas indicates a different course or severity of infection. It is not known what role lymphocyte apoptosis plays in human filoviral disease, but recent studies (Baize et al, 1999) suggest that it may be consistent with nonhuman primate models shown in this study. While the extent of lymphocyte apoptosis in EBO-Z and MBGinfected PBMC was similar, for EBO-R-infected PBMC, there were clearly fewer apoptotic lymphocytes. We are uncertain whether the reduced number that we observed was caused by differences in the release of soluble factors from infected cells, activation of infected cells, antigen processing and presentation, or interactions of virions or viral proteins with lymphocytes. It should also be noted that EBO-R has not been associated with fatal infection in humans (Peters et al, 1996).

Although definitive evaluation of the progression of apoptotic events in a model of lethal infection will require sequential killing of nonhuman primates, TEM of PBMC collected at various time points during EBO infection of cynomolgus monkeys showed an increase in lymphocyte apoptosis as early as Day 3 PI. (TW Geisbert, unpublished observation). Future studies will evaluate the sequence of apoptotic events in filovirusinfected animals and investigate the causes and effects of apoptosis in filoviral disease. The therapeutic implications of our findings are that pharmacologic intervention in $\mathrm{EBO}$ and $\mathrm{MBG}$ infections may require a two-pronged approach, with one agent designed to inhibit filoviral replication and a second agent designed to prevent apoptosis of bystander lymphocytes.

\section{Materials and Methods}

\section{Cells and Viruses}

PBMC were separated from heparinized peripheral blood collected from healthy donors by centrifugation on Histopaque (Sigma Chemical, St. Louis, Missouri) at $250 \times \mathrm{g}$ for 30 minutes. Cells at the interface were harvested and used as PBMC. After washing with RPMI 1640 medium, the cells were cultured in RPMI supplemented with $5 \%$ heat-inactivated human serum. Normal HMVEC were obtained from Clonetics, Inc. (San Diego, California), and maintained in endothelial cell growth medium (EGM; Clonetics), which was supplemented with human recombinant epidermal growth factor, hydrocortisone, fetal bovine serum, gentamicin, and bovine brain extract (Clonetics). HMVEC were maintained according to the supplier's recommendations. Viability for PBMC and HMVEC was estimated by the trypan-blue exclusion procedure and was greater than $99 \%$ in all preparations. Experimental infection conditions consisted of maintenance of $2.5 \times 10^{6}$ PBMC and $2.5 \times 10^{5}$ HMVEC in segregated cultures. Cells were infected at an m.o.i of 1.0 with EBO-Z virus isolated from a human patient in 1976 (Johnson et al, 1977), EBO-R virus isolated from a nonhuman primate in 1989 (Jahrling et al, 1990), or MBG (strain Musoke) virus isolated from a human patient in 1980 (Smith et al, 1982). PBMC were incubated in the presence of infectious virus for 3 hours at $37^{\circ} \mathrm{C}$, washed with RPMI, and replated in fresh medium. RPMI supplemented with $5 \%$ human serum from healthy donors was added, and incubation proceeded for the appropriate time at $37^{\circ} \mathrm{C}$. After adsorption with virus for 1 hour at $37^{\circ} \mathrm{C}$, HMVEC were washed twice with PBS, re-fed with fresh EGM, and incubated at $37^{\circ} \mathrm{C}$ as described for PBMC.

\section{In Vivo Infections}

Primates, which served as virus-infected controls in previous studies, were evaluated retrospectively to conserve primate resources (Jaax et al, 1996; Jahrling et al, 1996; Jahrling et al, 1999). Twenty-two nonhuman primates were employed for this study: five cynomolgus monkeys (Macaca fascicularis), three rhesus monkeys (Macaca mulatta), and four African green monkeys (Cercopithecus aethiops) inoculated im with $10^{3.0}$ pfu of EBO-Z virus, two cynomolgus monkeys inoculated im with $10^{5.0}$ pfu of EBO-R virus, and four cynomolgus monkeys inoculated im with $10^{3.0}$ pfu of MBG virus. All monkeys were killed in extremis between Days 6 and $15 \mathrm{PI}$. The four remaining monkeys (one cynomolgus, two rhesus, one African green) were uninfected controls.

\section{Light and Electron Microscopy}

Portions of liver; spleen; and mesenteric, axillary, and inguinal lymph nodes were immersion-fixed in $10 \%$ neutral buffered formalin and embedded in paraffin. For TEM, additional portions of these tissues were immersion-fixed in $2 \%$ glutaraldehyde in $0.1 \mathrm{M}$ Mil- 
lonig's phosphate buffer ( $\mathrm{pH}$ 7.4). Also, PBMC and HUVEC were processed for TEM as previously described for cultured cells (Geisbert and Jahrling, 1995). Briefly, tissues and cultured cells were postfixed in 1\% osmium tetroxide, rinsed, treated with $0.5 \%$ uranyl acetate in ethanol, dehydrated in ethanol and propylene oxide, and embedded in Poly/Bed 812 resin (Polysciences, Warrington, Pennsylvania). Areas to be evaluated by TEM were selected from 1- $\mu \mathrm{m}$ sections stained with toluidine blue. Ultrathin sections were cut, placed on 200-mesh copper TEM grids, stained with uranyl acetate and lead citrate, and examined with a JEOL 1200 EX transmission electron microscope (JEOL, Peabody, Massachusetts).

\section{In Situ TUNEL Staining}

Replicate sections (5 $\mu \mathrm{m})$ were floated on diethyl pyrocarbonate-treated water (Sigma), collected on Superfrost/plus slides (Fisher Scientific, Pittsburgh, Pennsylvania), and air dried. Sections were deparaffinized and rehydrated through graded alcohols to diethyl pyrocarbonate-treated water. Sections were stained for apoptosis with the in situ cell death detection kit (Roche, Indianapolis, Indiana) according to manufacturer's recommendations with minor modifications. Briefly, sections were treated with $10 \mu \mathrm{g} / \mathrm{ml}$ of proteinase $\mathrm{K}$ in PBS for 30 minutes at $37^{\circ} \mathrm{C}$, washed with PBS, treated with $50 \mu \mathrm{l}$ of the TUNEL reaction mixture, and incubated under a coverslip in a humidified chamber for 1 hour at $37^{\circ} \mathrm{C}$. The reaction was stopped by washing slides in $0.1 \%$ Triton plus $0.1 \%$ BSA in TBS for 15 minutes at room temperature. Sections were then incubated with the antifluorescein-alkaline phosphatase conjugate (Roche) diluted 1:3 in $100 \mathrm{~mm}$ Tris- $\mathrm{HCl}, 150 \mathrm{~mm} \mathrm{NaCl}(\mathrm{pH} 7.5)$, and $1 \%$ blocking agent for 30 minutes at $37^{\circ} \mathrm{C}$. After washing in TBS, sections were stained by incubation with a chromogenic substrate 5 bromo-4-chlor-3inolyl phosphate (X-phosphate/BCIP) and nitro blue tetrazolium salt at $37^{\circ} \mathrm{C}$ and counterstained with nuclear fast red.

\section{Immunohistochemistry: Detection of Viral Antigen}

Double-labeling experiments using TUNEL and IHC were conducted to determine whether filovirusinfected cells were undergoing apoptosis and to correlate the distribution of viral antigen with apoptotic cells. Sections were stained for apoptosis by the TUNEL assay (Roche) as described above and subsequently stained for viral antigen by the peroxidase Envision System (DAKO) as directed by the manufacturer with minor modifications. Briefly, TUNEL-treated sections were rinsed in PBS, treated with peroxidase block for 5 minutes at room temperature, rinsed in PBS, and incubated with normal goat serum for 20 minutes at room temperature. Serum was removed and sections were incubated with a mixture of mouse anti-EBO virus ascitic fluid (Jaax et al, 1996), or an isotype-identical mouse anti-MBG virus ascitic fluid (Jaax et al, 1996), diluted in antigen diluent with background-reducing components (DAKO) for 30 minutes at room temperature. Next, sections were incubated in the peroxidase-labeled secondary antibody for 30 minutes. After rinsing in PBS, sections were treated with substrate-chromagen solution for $8 \mathrm{~min}-$ utes at room temperature, rinsed in distilled water, and rinsed in PBS. Sections were subsequently counterstained with nuclear fast red.

\section{Immunohistochemistry: Detection of Cell Markers}

To facilitate detection of cell markers in conjunction with single-strand DNA breaks, an IHC assay was employed using rhodamine for detection of apoptosis and FITC or alexa 488 (Molecular Probes, Eugene, Oregon) for detection of cell markers. Sections were stained for apoptosis using the ApopTag assay (Intergen, Purchase, New York) as directed by the manufacturer. Sections were treated with $20 \mu \mathrm{g} / \mathrm{ml}$ of proteinase $\mathrm{K}$ for 30 minutes at $37^{\circ} \mathrm{C}$, washed in PBS, and placed in an equilibration buffer for 5 to 10 minutes. Excess equilibration buffer was removed, and sections were treated with reaction buffer containing deoxynucleotidyl transferase mediated enzyme for 1 hour at $37^{\circ} \mathrm{C}$. Sections were rinsed and incubated for 10 minutes at room temperature in the stop solution and washed in PBS. Anti-digoxigeninrhodamine was diluted in blocking buffer and incubated with the sections for 30 minutes at $37^{\circ} \mathrm{C}$. Sections were rinsed in PBS and incubated in normal goat serum for 20 minutes at room temperature. Serum was removed and sections were incubated with a pan $\mathrm{T}$ cell marker, CD3 (DAKO); a pan B cell marker, CD20 (DAKO); a plasma cell marker, NCL-PC (Novacastra); or a macrophage marker, Mac387 (Novacastra) for 1 hour at $37^{\circ} \mathrm{C}$, and rinsed in PBS. Sections stained with CD3 were treated with goat anti-rabbit alexa 488 (Molecular Probes) for 30 minutes at $37^{\circ} \mathrm{C}$. Sections stained with CD20 or NCL-PC were incubated in goat anti-rabbit FITC (Sigma) for 30 minutes at $37^{\circ} \mathrm{C}$. Sections were rinsed in PBS, mounted in an aqueous mounting medium, and examined using an Olympus BX fluorescence microscope (Olympus Optical, Lake Success, New York). Staining for apoptosis was visualized with a wide-band green filter, cell markers with a blue-band filter, and double labeling using a dual-pass FITC/TRITC filter.

To further assess the distribution of macrophages and plasma cells, sections of lymph nodes were pretreated with $20 \mu \mathrm{g} / \mathrm{ml}$ of proteinase $\mathrm{K}$ for 30 minutes at $37^{\circ} \mathrm{C}$, rinsed in PBS, and labeled using either NCL-PC (Novacastra) or Mac387 (Novacastra) in conjunction with the peroxidase Envision System (DAKO) according to manufacturer's directions. Sections were counterstained with hematoxylin. The Envision System (DAKO) was also used for cell markers that proved incompatible with the proteinase $\mathrm{K}$ pretreatment required for the TUNEL assay. Sections were stained with a CD4-specific antibody (clone 1F6) (Novacastra) or a CD8-specific antibody (clone C8/ 144B) (DAKO). Sections for CD8 detection were pretreated in citrate buffer $(\mathrm{pH} 6.0)$ at $94^{\circ} \mathrm{C}$ for 30 
minutes. Sections for CD4 staining were microwaved in $1.0 \mathrm{~mm}$ EDTA ( $\mathrm{pH}$ 8.0). After pretreatment, sections were rinsed in distilled water and PBS and incubated with peroxidase block at room temperature for 5 minutes. Sections were rinsed in PBS and treated with normal goat serum for 20 minutes at room temperature. Serum was removed and sections were incubated with the CD8 antibody diluted in antigen diluent with background-reducing components (DAKO) for 30 minutes at room temperature. Sections were rinsed in PBS and treated with substrate-chromagen solution for 8 minutes at room temperature, rinsed in distilled water, rinsed in PBS, and counterstained with hematoxylin.

\section{Morphometrical and Statistical Analysis}

From each animal, three lymph nodes (composite of axillary, inguinal, and mesenteric) were employed to evaluate and count cells. Areas of cortex were selected from 1- $\mu \mathrm{m}$ sections as described above. The mean number of total lymphocytes and the mean number of apoptotic lymphocytes were determined by counting the normal and apoptotic cells in 12 comparable electron micrographs at a magnification of $\times 2000$. Statistical analysis of parameters was performed using the StatView software package (Abacus Concepts, Berkeley, California). Means, standard deviations, and standard errors were calculated. Means were compared by using the nonparametric MannWhitney $U$ test (Mann and Whitney, 1947). For each monkey, the number of fields containing filoviral antigen (virions or cells with viral inclusion material) and apoptotic cells was tabulated and correlated by simple linear regression. For PBMC, the total number of lymphocytes and the number of apoptotic lymphocytes were determined by counting the normal and apoptotic cells in 30 comparable TEM fields at a magnification of $\times 2000$.

\section{Acknowledgements}

The authors thank Ms. Denise Braun, Mr. Wayne Kell, Ms. Lynda Miller, Mr. Larry Ostby, and Ms. Diecilla Sledge for their expert technical assistance. We are also grateful to Dr. Art Anderson for helpful discussions.

\section{References}

Afonso CL, Neilan JG, Kutish GF, and Rock DL (1996). An African swine fever virus Bcl-2 homolog, 5-HL, suppresses apoptotic cell death. J Virol 70:4858-4863.

Arends MJ and Wyllie AH (1991). Apoptosis: Mechanism and role in pathology. Int Rev Exp Pathol 32:223-254.

Baize S, Leroy EM, Georges-Courbot M-C, Capron M, Lansoud-Soukate J, Debre P, Fisher-Hoch SP, McCormick JB, and Georges AJ (1999). Defective humoral responses and extensive intravascular apoptosis are associated with fatal outcome in Ebola virus-infected patients. Nature Med 5:423-426.
Baskerville A, Fisher-Hoch SP, Neild GH, and Dowsett AB (1985). Ultrastructural pathology of experimental Ebola haemorrhagic fever virus infection. J Pathol 147:199-209.

Carroll MC (1998). CD21/CD35 in B cell activation. Semin Immunol 10:279-286.

Carrasco L, de Lara FC-M, de las Mulas LJM, GomezVillamandos JC, Perez J, Wilkinson PJ and Sierra MA (1996). Apoptosis in lymph nodes in acute African swine fever. J Comp Pathol 115:415-428.

Cheville NF (1994). Vascular Tissue. In: Cheville NF, editor: Ultrastructural Pathology. An Introduction to Interpretation. Ames, IA: lowa State University Press, 336-392.

Coito C and Bomsel M (1999). B7 cosignal potentiates apoptosis of uninfected $\mathrm{CD}^{+}{ }^{+} \mathrm{T}$ lymphocytic cell lines primed by HIV envelope proteins. AIDS Res Hum Retroviruses 15:509-521.

Collins JA, Schandl CA, Young KK, Vesely J, and Willingham MC (1997). Major DNA fragmentation is a late event in apoptosis. J Histochem Cytochem 45:923 934.

Connolly BM, Steele KE, Davis KJ, Geisbert TW, Kell WM, Jaax NK, and Jahrling PB (1999). Pathogenesis of experimental Ebola virus infection in guinea pigs. J Infect Dis (Suppl 1) $179: S 203-S 217$.

Davis KJ, Anderson AO, Geisbert TW, Steele KE, Geisbert JB, Vogel P, Connolly BM, Huggins JW, Jahrling PB, and Jaax NK (1997). Pathology of experimental Ebola virus infection in African green monkeys. Arch Pathol Lab Med 121: 805-819.

Debbas M and White E (1993). Wild-type p53 mediates apoptosis by E1A, which is inhibited by E1B. Genes Dev 7:546-554.

Eischen CM and Leibson PJ (1997). The Fas pathway in apoptosis. In: Kaufmann SH, editor: Advances in Pharmacology. San Diego: Academic Press, Inc., 107-132.

Feldmann H, Bugany H, Mahner F, Klenk H-D, Drenckhahn D, and Schnittler H-J (1996). Filovirus-induced endothelial leakage triggered by infected monocytes/macrophages. J Virol 70:2208-2214.

Fehsel K, Kroncke K-D, and Kolb-Bachofen V (1996). NO as a physiological signal molecule that triggers thymocyte apoptosis. Adv Exp Med Biol 387:195-198.

Finkel TH, Tudor-Williams G, Banda NK, Cotton MF, Curiel T, Monks C, Baba TW, Ruprecht RM, and Kupfer A (1995). Apoptosis occurs predominantly in bystander cells and not in productively infected cells of HIV- and SIV-infected lymph nodes. Nature Med 1:129-134.

Geisbert TW and Jaax NK (1998). Marburg hemorrhagic fever: Report of a case studied by immunohistochemistry and electron microscopy. Ultrastr Pathol 22:3-17.

Geisbert TW and Jahrling PB (1995). Differentiation of filoviruses by electron microscopy. Virus Res 39:129-150.

Geisbert TW, Jahrling PB, Hanes MA, and Zack PM (1992). Association of Ebola related Reston virus particles and antigen with tissue lesions of monkeys imported to the United States. J Comp Pathol 106:137-152.

Granville DJ, Carthy CM, Hunt DWC, and McManus BM (1998). Apoptosis: molecular aspects of cell death and disease. Lab Invest 78:893-913. 
Gretz JE, Kaldjian EP, Anderson AO, and Shaw S (1996). Sophisticated strategies for information encounter in the lymph node. The reticular network as a conduit of soluble information and a highway for cell traffic. J Immunol 157:495499.

Griffith TS, Wiley SR, Kubin MZ, Sedger LM, Maliszewski CR, and Fanger NA (1999). Monocyte-mediated tumoricidal activity via the tumor necrosis factor-related cytokine, TRAIL. J Exp Med 189:1343-1353.

Grimley PM, Kang $\mathrm{YH}$, Silverman $\mathrm{RH}$, Davis G, and Hoofnagle JH (1983). Blood lymphocyte inclusions associated with alpha interferon. Lab Invest 48:30A-31A.

Grosjean I, Caux C, Bella C, Berger I, Wild F, Banchereau J, and Kaiserlian D (1997). Measles virus infects human dendritic cells and blocks their allostimulatory properties for CD4 ${ }^{+} \mathrm{T}$ cells. J Exp Med 186:801-812.

Harmon BV, Winterford CM, O’Brien BA, and Allan DJ (1998). Morphological criteria for identifying apoptosis. In: Celis JE, editor: Cell Biology A Laboratory Handbook. San Diego: Academic Press Inc., 327-340.

Henderson S, Rowe M, Gregory C, Croom CD, Wang F, Longnecker R, Kieff E, and Rickinson A (1991). Induction of bcl-2 expression by Epstein-Barr virus latent membrane protein 1 protects infected $B$ cells from programmed cell death. Cell 65:1107-1115.

Ignat'ev GM, Strel'tsova MA, Agafonov AP, and Kashentseva EA (1995). Mechanisms of protective immune response in models of Marburg fever in monkeys. Vopr Virusol 40:109113.

Jaax NK, Davis KJ, Geisbert TW, Vogel P, Jaax GP, Topper $M$, and Jahrling PB (1996). Lethal experimental infection of rhesus monkeys with Ebola-Zaire (Mayinga) virus by the oral and conjunctival route of exposure. Arch Pathol Lab Med 120:140-155.

Jahrling PB, Geisbert TW, Dalgard DW, Johnson ED, Ksiazek TG, Hall WC, and Peters CJ (1990). Preliminary report: Isolation of Ebola virus from monkeys imported to USA. Lancet 335:502-505.

Jahrling PB, Geisbert TW, Jaax NK, Hanes MA, Ksiazek TG, and Peters CJ (1996). Experimental infection of cynomolgus monkeys with Ebola-Reston filoviruses from the 1989-1990 U. S. epizootic. Arch Virol (Suppl 1) 11:115-134.

Jahrling PB, Geisbert TW, Geisbert JB, Swearengen JR, Bray M, Jaax NK, Huggins JW, LeDuc JW, and Peters CJ (1999). Evaluation of immune globulin and recombinant Interferon$\alpha 2 b$ for treatment of experimental Ebola virus infections. J Infect Dis (Suppl 1) 179:S224-S234.

Johnson KM, Webb PA, Lange JV, and Murphy FA (1977). Isolation and partial characterization of a new virus causing acute hemorrhagic fever in Zaire. Lancet 1:569-571.

Kayagaki N, Yamaguchi N, Nakayama M, Eto H, Okumura K, and Yagita $H$ (1999). Type I interferons (IFNs) regulate tumor necrosis factor-related apoptosis-inducing ligand (TRAIL) expression on human $T$ cells: A novel mechanism for the antitumor effects of type I INFs. J Exp Med 189:1451-1460.

Kerr JFR, Wyllie AH, and Currie AR (1972). Apoptosis: A basic biological phenomenon with wide-ranging implications in tissue kinetics. Br J Cancer 26:239 257.

Kolesnick R and Golde DW (1994). The sphingomyelin pathway in tumor necrosis factor and interleukin-1 signaling. Cell 77:325-328.
Lewis J, Wesselingh SL, Griffin DE, and Hardwick M (1996). Alphavirus-induced apoptosis in mouse brains correlates with neurovirulence. J Virol 70:1828-1835.

Lindhout E, Lakeman A, and de Groot C (1995). Follicular dendritic cells inhibit apoptosis in human $\mathrm{B}$ lymphocytes by a rapid and irreversible blockade of preexisting endonuclease. J Exp Med 181:1985-1995.

Little SP and Huang AS (1978). Shedding of the glycoprotein from vesicular stomatitis virus-infected cells. J Virol 27:330339.

Lu L, Qian S, Hershberger PA, Rudert WA, Lynch DH, and Thompson AW (1997). Fas ligand (CD95L) and B7 expression on dendritic cells provide counter-regulatory signals for $\mathrm{T}$ cell survival and proliferation. J Immunol 158:5676-5684.

Majno $G$ and Joris I (1995). Apoptosis, oncosis, and necrosis: An overview of cell death. Am J Pathol 146:3-15.

Mann HB and Whitney DR (1947). On a test of whether one or two random variables is stochastically larger than the other. Ann Math Statist 18:50-60.

Martin JH and Edwards SW (1993). Changes in mechanisms of monocyte/macrophage-mediated cytotoxicity during culture. Reactive oxygen intermediates are involved in monocyte-mediated cytotoxicity whereas reactive nitrogen intermediates are employed by macrophages in tumor cell killing. J Immunol 150:3478-3486.

Messmer UK, Ankarcrona M, Nicotera P, and Brune B (1994). p53 Expression in nitric oxide-induced apoptosis. FEBS Lett 355:23-36.

Murphy FA, Fauquet CM, Bishop DHL, Ghabrial SA, Jarvis AW, Martelli GP, Mayo MA, and Summers ED (1995). Virus taxonomy: Classification and nomenclature of viruses. Sixth Report of the International Committee on Taxonomy of Viruses. Arch Virol Suppl 10:265-292.

Nahar TO, Williams NA, and Hirst TR (1996). Cross-linking of cell surface ganglioside GM1 induces the selective apoptosis of mature $\mathrm{CD}^{+}$lymphocytes. Int Immunol 8:731-736.

Oberhaus SM, Smith RL, Clayton GH, Dermody TS, and Tyler KL (1997). Reovirus infection and tissue injury in the mouse central nervous system are associated with apoptosis. J Virol 71:2100-2106.

Oura CAL, Powell PP, and Parkhouse RME (1998). African swine fever: a disease characterized by apoptosis. J Gen Virol 79:1427-1438.

Peters CJ, Sanchez A, Rollin PE, Ksiazek TG, and Murphy FA (1996). Filoviridae: Marburg and Ebola viruses. In: Fields BN, Knipe DM, Howley PM, et al, editors: Fields Virology. Philadelphia: Lippincott-Raven Publishers, 1161-1176.

Rosenberg YJ, Anderson AO, and Pabst R (1998). HIVinduced decline in blood CD4/CD8 ratios: Viral killing or altered lymphocyte trafficking? Immunol Today 19:10-16.

Ryabchikova El, Kolesnikova LV, and Luchko SV (1999). An analysis of features of pathogenesis in two animal models of Ebola virus infection. J Infect Dis (Suppl 1) 179:S199-S202.

Schattner E and Friedman SM (1996). Fas expression and apoptosis in human B cells. Immunol Res 15:246-257.

Schnittler H-J, Mahner F, Drenckhahn D, Klenk H-D, and Feldmann H (1993). Replication of Marburg virus in human endothelial cells. A possible mechanism for the development of viral hemorrhagic disease. J Clin Invest 91:1301-1309. 
Smith DH, Johnson BK, Isaacson M, Swanepoel R, Johnson KM, Kiley MP, Bagshawe A, Siongok T, and Keruga WK (1982). Marburg virus disease in Kenya. Lancet 1:816-820.

Sur J-H, Doster AR, and Osorio FA (1998). Apoptosis induced in vivo during acute infection by porcine reproductive and respiratory syndrome virus. Vet Pathol 35:506-514.

Tracey KJ and Cerami A (1992). Tumor necrosis factor-alpha. In: Roitt IM and Delves JM, editors: Encyclopedia of Immunology. San Diego: Academic Press Inc., 1522-1524.

Tew JG, Wu J, Qin D, Helm S, Burton GF, and Szakal AK (1997). Follicular dendritic cells and presentation of antigen and costimulatory signals to B cells. Immunol Rev 156:3952.

Trump BF, Berezesky IK, Chang SH, and Phelps PC (1997). The pathways of cell death: Oncosis, apoptosis and necrosis. Toxicol Pathol 25:82-88.

Veronese FD, Devico AL, Copeland TD, Oroszlan S, Gallo RC, and Sarngadharan MG (1985). Characterization of gp41 as the transmembrane protein coded by the HTLV-III/LAV envelope gene. Science 229:1402-1405.
Villinger F, Rollin PE, Brar SS, Chikkala NF, Winter J, Sundstrom B, Zaki SR, Swanepoel R, Ansari AA, and Peters CJ (1999). Markedly elevated levels of interferon (IFN)- $\alpha$, IFN- $\gamma$, interleukin (IL)-2, IL-10, and tumor necrosis factor- $\alpha$ associated with fatal Ebola virus infection. J Infect Dis (Suppl 1) 179:S188-S191.

Volchkov VE (1999). Processing of the Ebola virus glycoprotein. Curr Top Microbiol Immunol 235:35-47.

Walker LS, McLeod JD, Boulougouris G, Patel YI, Hall ND, and Sansom DM (1998). Down-regulation of CD28 via Fas (CD95): Influence of CD28 on T-cell apoptosis. Immunology 94:41-47.

Yang Z, Delgado R, Xu L, Todd RF, Nabel EG, Sanchez A, and Nabel GJ (1998). Distinct cellular interactions of secreted and transmembrane Ebola virus glycoproteins. Science 279: 1034-1037.

Zaki SR and Goldsmith CS (1999). Pathologic features of filovirus infections in humans. Curr Top Microbiol Immunol 235:97-116. 